\title{
Managing Village Governance Based On Mutual Assistance (Gotong Royong)
}

\author{
Kushandajani \\ Universitas Diponegoro \\ Semarang, Indonesia \\ ningpemfisip_undip@yahoo.co.id
}

\author{
Puji Astuti \\ Universitas Diponegoro \\ Semarang, Indonesia
}

\begin{abstract}
Law No. 6 of 2014 on Village constructs village authority in four areas: managing village governance, implementation of rural development, coaching rural community, and empowerment of rural community. Those are the basis of village governance, including the organizational structure of the village government. Then, how does the village government respond to the changes since the enactment of Law No. 6 of 2014 on Village? The answer to the question become the focus of this study. Qualitative research method was chosen, by using perspective of emic. Data collection techniques prioritized the use of first hand data, which were obtained from several informants through in-depth interviews and focused group discussion (FGD). The result of this study shows that managing village governance is a concept that is integrated and could not be separated from other functions, namely implementation of rural development, coaching rural community, and empowering rural community. Instead, the last function, the empowerment of rural community, animating other functions through local value called mutual assistance (gotong royong). The conclusion of this study shows that the state are being ambiguous to the village.
\end{abstract}

Keywords—village governance, social capital, local wisdom, organizational structure of village government.

\section{INTRODUCTION}

Village, socially and politically, has a very strong position in Indonesia. With around 73,000 (seventy three thousand) villages and about 8,000 (eight thousand) kelurahans, shows that Indonesian mostly live in villages. Thus, the position of village government also has strategic significance, since the village government is the one who is closest to the people. In the history of village structuring, there have been several regulations on village, those are Law No. 22 of 1948 on Basic Principles of Regional Government; Law No. 1 of 1957 on Fundamentals of Regional Government; Law No. 18 of 1965 on Fundamentals of Regional Government; Law No. 19 of 1965 on Civil Village; Law No. 5 of 1974 on Fundamentals of Regional Government; Law No. 5 of 1979 on Village Government; Law No. 22 of 1999 on Regional Government; Law No. 32 of 2004 on Regional Government; and lastly, Law No. 6 of 2014 on Village. The state policy on village, through law, which was made from a certain period of time to the next, has different meaning to the administration of the village. The interpretation of each law will have implications on the social meaning of the administration of the village as well.

Currently, the existence of village is regulated in Law No. 6 of 2014 on Village, which constructs the authority of villages in four areas: managing village governance, implementation of rural development, coaching rural community, and empowerment of rural community. Those authorities, are the basis for the village administration. On the other hand, during this time, the village government and the villagers basically explain village governance based on the values prevailing in the local village community, which is called mutual assistance (gotong royong). Research aims are to know how does the village government respond to the enactment of Law No 6 of 2014 on Village and Could mutual assistance still be strong and thrive in the governance of the village.

\section{RESEARCH METHODOLOGY}

Looking back at the purpose of this research that reveals whether there is any research findings, this research is in the category of exploratory research with qualitative method. The study was conducted in Desa Lerep (Lerep Village), Kecamatan Ungaran Barat (West Ungaran District), Kabupaten Semarang (Semarang Regency). The determination of informants was using purposive sampling. This study prioritized the use of first hand data, through in-depth interview with informants. Meanwhile, secondary data were obtained through library research, previous studies, numbers from government agencies, as well as rules and regulations governing the village. The study also prioritizes emic perspective, that is concerned with the views of informants, which is about how he looked at and interpret the world [1]. Thus, this study is not intended to seek a broad generalization, because the finding depends on the interaction between the researcher and the research subject, where the actors have a place to play its role [2].

\section{RESULT AND DISCUSSION}

Desa (village), is a Javanese term which refers to indigenous people in Java [3]. In Java, desa is a community of law, because it consists of a group of men who have structural arrangement, with officials; have territory and property; acts as a unity to the outside world; and may not be terminated [4]. [5] classifies "native village" based on shared territory (territoriale rechtsgemeeens happen), which is mostly in Java and Madura; and by descent (genealogische rechtsgemeeenshappen), which is mostly outside Java and Madura. In a sociological perspective, desa is also seen as a form of common life, which consists of several thousand people, where almost all of them know each other; mostly work in agriculture; family ties are close; and adhere to the traditions and social forms [6]. 
In the hierarchical system of government in Indonesia, desa is located below kecamatan (district). Desa is divided into dusun (hamlets), then rukun warga (RW or a citizen association), and rukun tetangga (RT or a neighborhood association), as seen in the following figure:
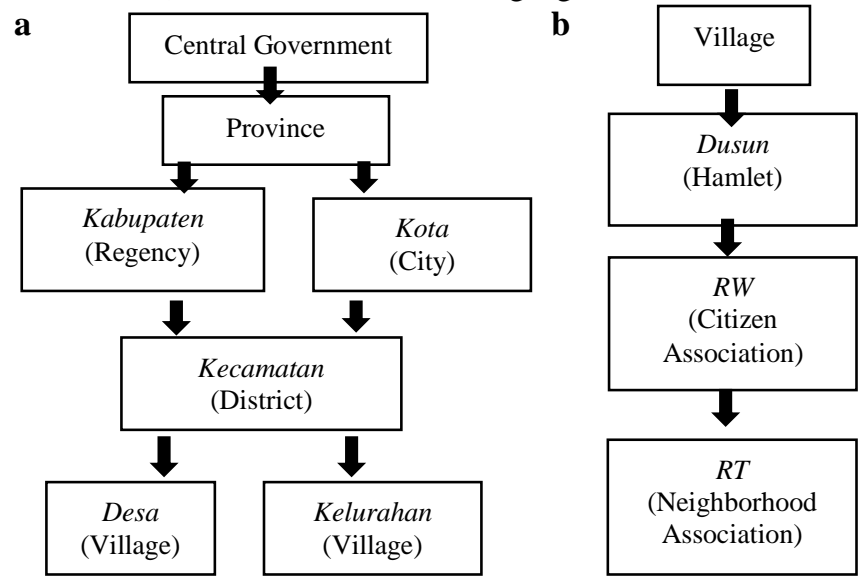

Fig.1: (a) The Government Hierarchy in Indonesia; (b) The Division in Desa

Something similar to the figure above could be observed in Desa Lerep, where this study was conducted. Desa Lerep is located in Kecamatan Ungaran Barat, Kabupaten Semarang. Overall, Desa Lerep has an area of 682.32 hectares, or approximately $18.96 \%$ of Kecamatan Ungaran Barat (3596.05 ha), or $0.72 \%$ of Kabupaten Semarang (95020.67 ha). Administratively, Desa Lerep consists of 8 dusun, $10 \mathrm{RW}$, and 65 RT. Desa Lerep, geographically benefit; given its strategic position in the center of Kecamatan Ungaran Barat. Furthermore, based on Semarang Regency Regulation No. 11 of 2007, Desa Lerep was set as the capital city of Kecamatan Ungaran Barat; as a result of expansion Kecamatan Ungaran into two, namely Kecamatan Ungaran Barat and Kecamatan Ungaran Timur.

Desa Lerep, as well as other villages in Indonesia, has the right to autonomy in organizing its administration. Meanwhile, kelurahan does not have it. The autonomy of desa could be seen from several indicators. First, from how to choose the leader. In desa, the head is elected directly by the villagers, while in kelurahan, the head is appointed by the regent or mayor. Autonomy of desa could also be seen from the village government's rights to formulate and execute its own budget, or the so-called Anggaran Pendapatan dan Belanja Desa (APBD desa or village budget). Meanwhile, the budget of kelurahan is part of Anggaran Pendapatan dan Belanja Daerah (APBD, or local budget), whether from kabupaten or the city. Desa has an autonomous village government structure, while kelurahan does not have it, since kelurahan is structurally part of local government (kabupaten or city). From the aspect of authority, kelurahan only implement the regional authority, in accordance with the assignment of the regent or mayor. As for desa, it has authority under the right of the origin of the village and village scale local authority, as well as having authority assigned by the Central Government, Provincial Government, or Local Government (kabupaten or city); and other authorities assigned by the Central Government, Provincial Government, or the Local Government (kabupaten or city), in accordance with the rules in the legislation. The authority based on the right of origin of the village comprises of [7]: (a) the organizational system of village forces; (b) the organizational system of traditional society; (c) the development of social institutions; (d) the development of traditional institution and laws; (e) the management of land as the treasury of the village; (f) the management of village lands or the land properties of the village with local naming; (g) the management of bengkok lands; (h) the management of pecatu lands; (i) the management of titisara lands; and (j) the development of societal roles of the village.

The construction of village governance in Law No. 6 of 2014 on Village concerns several important things. First, village governance is run by the village government, consisting of the head of the village (kepala desa) and village officials (perangkat desa). Secondly, regarding duties, powers, rights, and the liabilities of the head of the village. Third, regarding the obligation of the head of the village to the regent, as his head. Fourth, regarding the dismissal of the head of the village and the suspension of the head of the village. Fifth, is about the setting of the village. Sixth, regarding the setting of musyawarah desa (village meetings). Seventh, regarding the setting of Badan Permusyawaratan Desa (BPD or Village Consultative Body). Lastly, regulation regarding the village government revenue. Observing the construction above, it could be concluded that the administration of the village is attached to the duties, powers, rights, and obligations of the head of the village, helped by its officials.

In addition to running the village governance or administration, the head of the village also undertake rural development, coaching rural community, and empower rural community. Are those four areas work seperately and has its own meaning? In reality, the implementation of rural development, coaching rural community, and the empowerment of rural community, are integral part of village governance. The success of the head of the village in governing the village could be measured by its ability to undertake development, society, as well as community empowerment. In fact, the ability of the head of the village in empowering rural community or villagers, would have impact on the level of community participation, which is the main support of village governance. For lurah (head of) Desa Lerep, empowerment of rural community, widely, is the main spirit of village governance. When lurah is capable in empowering community, it would directly encourage community participation, and in the end, the rural development program could be implemented easily. It is a reflection of one of the characters of desa, known as melu handarbeni (=an assumption that, development is a joint responsibility). In this regard, for example, there is a common value in Desa Lerep in road improvement, that is: "if we happen to see a damaged road in the village, let's ngrogoh kantong yo gelem (donate from our own pocket; it is not a problem)". This is a manifestation of gotong royong of the villagers, which is very 
well preserved, and cultivated by the lurah. [8] argues that gotong royong has become a key element in the Indonesian system of political and cultural power through three cotinuing processes: 1) the motivated misrecognition of local cultural realities; (2) the construction of a national tradition on the basis of those misrecognation; and (3) the inclusion of state cultural representations as part of strategy of intervention in the rural sector and the mobilization of rural labor.

Local wisdom is still maintained by the people of Desa Lerep, such as procedure in maintaining and preserving water source, known as iriban tradition, which is held twice a year. Villagers bring various animals that are still alive, and they would slaughter the animals near the water source. Gotong royong could be seen from the distribution of duties; one-tenth of the villagers slaughter the animal, and the other nine-tenths clean up around the water source. If the villagers see plants that are damaged, they would replanted it, because large plants with certain age would be very useful in capturing more of rainwater. In fact, lurah Desa Lerep encourage the villagers to respect the sanctity of plants that grow around the water source through myth that is developed in the village, that is, "the tree has soul". As a result, people do not have guts in cutting trees around the water source; even just the twigs. Thus, the woods around the water source is looked after. In social norm of Desa Lerep, rules that is applied in the villagers is strengthened, in order to generate positive reciprocity; emerge cooperation and trust; and create positive behavior.

From organizational aspect, the government of Desa Lerep implement two structures that is coincide with one another. The first structure, call it the traditional structure, facilitate social norms of villagers with lurah (head of the village) and pamong desa (village officials) that consists of carik (secretary of the village), bekel (head of the hamlet), and modin (head of public affairs), which together with all the traditional rights, such as bengkok palungguh (the right of management given to the head of the village and village officials), and bengkok pangarem-arem (the right of management of the head of the village and the village officials who had completed his tenure). The second structure, the modern structure, is based on state law, that is, Law No. 6 of 2014 on Village, where the implementation is stipulated in Regulation of Minister of Home Affairs No. 84 of 2015 on Organizational Structure and Working System of Village Government. In the regulation, the terms used are kepala desa (head of the village) and perangkat desa (village officials) which consists of sekretaris desa (secretary of the village), kepala dusun (head of the hamlet), kepala urusan (head of affairs), kepala seksi (head of divisions or sections). In the daily administrative behavior, Desa Lerep still uses the traditional term. The term of pamong desa has stronger social meaning than legal meaning. According to the existing traditional value, the requirements for pamong desa is not complicated. The most important things are, good intentions and willingness to serve and taking care (ngemong) of the villagers. Every one in pamong desa has specific function, which requires dedication, and away from economic motives. All that is done would be given award, which is more social-religious than economic. Recognition and respect from the villagers is an honor; better than salaried. Intentions and good will in bringing the hope of the villagers, as well as obligation attached to the social status of pamong desa, is the hallmark of a strong social capital. As stated by [9], there are three forms of social capital are examined: obligation and expectation, information channels, and social norms. Thus, pamong desa is a form of social order, on the basis of certain values. Pamong desa is a result of the process of socialhistorical of the villagers, which reflect the conditions and the values that exist in the villagers, which is unique, special, and local.

From the financial aspect of the village, gotong royong could be traced through APBD desa, wherein gotong royong could be calculated economically. In the following table, it appears that selfhelp, participation, and voluntary donation from the villagers, are the manifestation of gotong royong, in order to realizing common interest of the villagers.

Table 1. The Structure of Village Budget (Anggaran

Pendapatan dan Belanja (APBDesa)) of Desa Lerep Year 2016

\begin{tabular}{ll}
\hline Source of Income & $\begin{array}{l}\text { Total Budget } \\
(\mathrm{Rp})\end{array}$ \\
\hline 1. Own-Source Revenue & $933,779,000$ \\
$\quad$ (Pendapatan Asli Daerah (PAD)) & \\
1.1. Revenue from Village Companies & - \\
$\quad$ (Hasil Usaha) & \\
1.2. Revenue from Village-Owned & - \\
$\quad$ Enterprises (Hasil Badan Usaha & \\
Milik Desa (BUMDes)) & \\
2. Revenue from Village Asset & $100,585,000$ \\
(Hasil Aset Desa) & $100,585,000$ \\
2.1. Village Land (Tanah Desa) & $9,505,000$ \\
2.2. Village Treasury Land (Tanah & $91,080,000$ \\
Kas Desa) & $\mathbf{7 8 4 , 1 5 0 , 0 0 0}$ \\
2.3. Salary Land (Tanah Bengkok) & $\mathbf{4 6 4 , 3 5 0 , 0 0 0}$ \\
3. Selfhelp, Participation and & $\mathbf{3 1 9 , 8 0 0 , 0 0 0}$ \\
$\quad$ Donation (from villagers) & $49,044,000$ \\
3.1. Selfhelp and Participation & (villagers)
\end{tabular}
(villagers)

3.2. Gotong Royong

$10,316,000$

4. Other Own-Source Revenue

4.1. Voluntary Donations to the Village Administrative Services (Sumbangan Sukarela pada Jasa Pelayanan Administrasi Desa)

4.2. Interest of Savings in Bank

4.3. Spending of Silpa ${ }^{1}$ Year 2015
465,250

$38,262,750$
From the table above, it could be concluded that selfhelp, participation, and gotong royong of the villagers of Desa Lerep contributed the most, which reached $83.87 \%$ in 2016.

Various descriptions suggest that, gotong royong is a manifestation of social capital in the village. The strength of social capital will determine the trust of the villagers to the lurah, pamong desa, and othe village institutions that hold the 
attributes of power in the village. Social capital would become stronger, if there is a norm of reciprocal help and strong cooperation, through a network of social institutional relations. Values of reciprocity, moral responsibility, obligation to the villagers, and trust that is not based on rational calculation but rather on custom, are needed [10]. As in China, the current rural community self-organizing of China is closely related with the rural social stability as well as economic and social development [11]. There is a tendency, if social capital could grow and established well, then the principle of governance is already obtained, and it is certain that the governance process would run smoothly. This happens because, there are three fundamental pillars that lie within social capital: trust, cooperation and the principle of general reciprocity [12]. If the villagers do not trust their government, would they be willing to work with the government to achieve the common goals? Social capital refers to connections among individuals, based on norms and networks of cooperation and trust, which spills over to the market and state to enhance collective action between formal actors and achieve improved social efficiency and growth [13]. Agrowing belief exists that social capital contributes to economic growth of communities [14]. For [15], there are two important things in social capital:

1. Social capital generally refers to trust, concern for ones associates, a willingness to live by the norms of one's community and to punish those who do not; and

2. By community governance we mean the structure of small group social interactions - distinct from markets and states - that, along with these more familiar forms of governance, jointly determine economic and social outcomes.

\section{CONCLUSIONS}

The desired value of Article 3 of Law No. 6 of 2014 on Village, namely the principle of recognition, subsidiarity; diversity; togetherness; gotong royong; kinship; discussion (musyawarah), democracy; self-reliance; participation; equality; empowerment; and sustainability, are expected to cling to the real condition in desa. Although on the one hand the State recognizes the autonomy of desa to govern and on the other hand treated desa as part of kabupaten, but desa is still able to maintain the spirit of gotong royong as the soul of governance in the village.

Managing village governance is a concept that is integrated and could not be seperated from other functions, namely the implementation of rural development, coaching rural community, and empowerment of rural community. Instead, the last function, the empowerment of rural community, animating other functions through local value known as gotong royong. Gotong royong reflects strong social capital, which creates mutual trust between the village government and the villagers. The village government tried hard to maintain the value of gotong royong, because without that value, the village government would not be able to carry out rural development, coaching rural community, and manage the administrative services in the village governance.

\section{ACKNOWLEDGEMENTS}

We thank all those involve in this research, especially Lurah Desa Lerep and rural residents in Desa Lerep, Kecamatan Ungaran Barat, Kabupaten Semarang.

\section{REFERENCES}

[1] Nasution, S. 1996. Metode Penelitian Naturalistik Kualitatif. Bandung: Transito, 1996.

[2] Ashshofa, Burhan. (2004). Metode Penelitian Hukum. Cet.IV. Jakarta: Rineka Cipta.

[3] Soekanto, Soerjono. (1986). Kedudukan Kepala Desa sebagai Hakim Perdamaian, Jakarta: Rajawali.

[4] Soepomo, R. (1984). Bab-Bab tentang Hukum Adat. Jakarta: Pradnya Paramita.

[5] Kartohadikoesoemo, Soetardjo. (1965). Desa. Bandung: Sumur.

[6] Ibrahim, Jabal Tarik. (2003). Sosiologi Pedesaan. Malang: Universitas Muhammadiyah Malang.

[7] Kushandajani. (2016).Village Authority Based On Indigenous Right and Local Scale Authoritu: Implications of Law No. 6/2014 Towards Village Auothority. Proceedings International Conference on Social Politics. , JK School of Government, Vol. 1, 111-121.

[8] Bowen, John R. (1986). On the Political Construction of Tradition: Gotong Royong in Indonesia. The Journal of Asian Studies (19861998); May 1986, Vol. 45, No. 3. Arts \& Humanities Database pg. 545.

[9] Coleman, James S. Social. (1988). Capital in the Creation of Human Capital. The American Journal of Sociology, Vol. 94, Supplement: Organizations and Institutions: Sociological and Economic Approaches to the Analysis of Social Structure (1988), pp. S95-S120 Published by: The University of Chicago Press.

[10] Fukuyama, Francis. (1995). Trust: The Social Virtues and the Creation of Prosperity. New York: The Free Press.

[11] WANG, Shousung. (2015). Inquiry of modernization management of rural community self-organizing on the perspective of Social Work. Agriculturural Science \& Technology, 16 (1), 140-155.

[12] Sedano, Alfredo Rodríguez-1, Ana Costa-Paris1, Juan Carlos Aguilera2. (2012) . Social Capital: Foundations and Some Social Policies in the EU . Sociology Mind. Vol.2, No.4, 342-346 .

[13] Kavee, Esther. (2016). Influence Of Social Capital On The Performance Of Small And Medium Enterprises In Nairobi County Kenya. Journal Of Applied Management Science, Vol. 2 Issue 4 April Paper 3.

[14] Anil Rupasingha a., Stephan J. Goetz , and David Freshwater (2006). The production of social capital in US counties. The Journal of SocioEconomics 35, 83-101.

[15] Bowles, Samuel and Herbert Gintis. (2002). Social Capital and Community Governance. The Economic Journal, November, 419-436. 